\title{
EDITORIAL
}

\section{LA EDUCACión MÉdica en Colombia}

\author{
Ricardo H. Rozo Uribe, MD. ${ }^{1}$, Ricardo H. Escobar Gaviria, MD. ${ }^{2}$ \\ ${ }^{1}$ Director Ejecutivo ASCOFAME. ${ }^{2}$ Jefe División Educación e Investigación ASCOFAME
}

\begin{abstract}
Indudablemente durante los últimos tres lustros se han presentado importantes cambios de orden cuantitativo en la educación médica del país que han prendido las alertas sobre un probable deterioro de la calidad de la misma. La oferta nacional de programas de medicina se incrementa en estos años en algo más del ciento cincuenta por ciento pasando de 21 en 1992 a 59 en 2011. La oferta regional en algunos casos llega a multiplicarse mucho más.
\end{abstract}

Parece sin embargo procedente afirmar que estos cambios no se dan de manera espontánea y que obedecieron a una política orientada hacia la apertura, no solo de los mercados, sino de todos los sectores sociales, y que en el caso que nos toca incluyó la Ley 100 de 1993 y la Ley 30 de 1992. La primera estableció un Sistema General de Seguridad Social, con un componente de salud que pretendía en pocos años cobertura universal, y la segunda reguló (desreguló?) la educación superior y brindó las condiciones legales que facilitaron el incremento de facultades de medicina y en general de todas la disciplinas.

Sin embargo, más allá de los significativos cambios cuantitativos que se han dado en la oferta de programas de medicina, es necesario decir que el país ha venido instaurando una serie de instrumentos de aseguramiento de la calidad (tanto generales de la educación superior, como específicos para salud) que han incidido en la formación del médico tratando de remediar dos situaciones que se presentaron como consecuencia de las mencionadas leyes: la falta de regulación a los nuevos programas y el deterioro de las relaciones docencia servicio.

La Acreditación de Alta Calidad ante el Consejo Nacional de Acreditación (CNA) es indudablemente un instrumento de gran importancia para la promoción y reconocimiento de la calidad de las facultades de medicina; en el país 21 facultades han sido acreditadas por una, dos y hasta tres veces. Este ha constituido indudablemente un esfuerzo significativo que hace visible a las facultades con vocación de calidad. ASCOFAME ha participado de manera activa en el acompañamiento de este proceso tanto a las facultades como con el CNA, y promueve dentro de sus estatutos la obligatoriedad de que sus facultades afiliadas se vinculen al mismo.

Del proceso sin embargo surgen algunas inquietudes que es conveniente explorar:

¿Qué pasa con las facultades que no logran acreditarse? Esto por lo demás es un enigma. La resolución de acreditación es pública, pero cuando la acreditación se niega el resultado no se hace conocer. ¿Sería conveniente, como mecanismo de control y responsabilidad social que el Ministerio de Educación Nacional hiciera conocer los resultados negativos? ¿El hecho de que el proceso de Acreditación sea voluntario implica que los resultados negativos no puedan ser públicos? ¿Qué pasa con las que, sin justificación alguna (por ejemplo estar adelantando procesos de acreditación internacional), no quieran acreditarse? Si el proceso de acreditación se hiciera obligatorio, la pregunta que surge es ¿si el techo se vuelve piso, habrá que crear otro techo?

La legitimidad e importancia del proceso es clara, pero no se puede permitir que al mismo solo estén vinculadas los programas que per se desarrollan procesos de calidad. Es necesario que el proceso tenga una mayor cobertura y que se instalen mecanismos que estimulen la vinculación de todos los programas del país, y las sanciones sociales que hagan que quienes no se vinculen no puedan permanecer vigentes.

Pero la calidad de la educación médica no depende de manera exclusiva de la institución universitaria. Los proyectos educativos que se gestan en la universidad se plasman en gran medida en los hospitales con los cuales se desarrollan los convenios de docencia servicio y, a pesar de los intentos de regular esta relación, hasta ahora el modelo no permite una interacción efectiva entre las partes, en beneficio de la formación del médico.

La coexistencia de varios programas de medicina (por lo tanto de proyectos educativos) en un mismo escenario de 
práctica hace que el proyecto educativo quede en manos de la institución de servicios, la cual no tiene un proyecto desarrollado, con frecuencia no cuenta con una estructura que le permita administrar la docencia y la universidad pierde la posibilidad de hacer seguimiento y evaluación a los procesos formativos y el control del desarrollo académico del programa.

El esfuerzo que se hace desde el sector educación para tener programas acreditados y de buena calidad, termina con un proyecto educativo que muere en una institución de servicios donde confluyen múltiples instituciones formadoras, y se tienen pocos avances en el proceso de acreditación de la calidad de las instituciones prestadoras de servicios de salud.

El tema de docencia servicio requiere de una gran voluntad política de múltiples sectores para que pueda ser resuelto de manera adecuada. La Ley 1438 de 2011, que reforma la Ley 100 de 1993 muestra algunos caminos para darle salida al problema que esperamos que se concreten en la reglamentación.

Dos temas más merecen una especial atención dentro de la multiplicidad de variables que inciden sobre la calidad del médico: la formación y competencias del docente y el perfil de formación profesional que se busca.

Sobre la formación docente ya desde los años 60 del pasado siglo se afirmaba que no era suficiente ser buen médico para ser buen profesor de medicina, situación que cada vez es más evidente. En los últimos cinco años hemos venido insistiendo en las competencias de formación de los estudiantes pero poco en las competencias de quienes los deben formar.

Además del dominio de los contenidos que se deben impartir el docente debe contar con una preparación que le permita entender los procesos de enseñanza aprendizaje, utilizar apropiadamente las metodologías existentes, entre otras las TIC; hacer una abordaje ético de las situaciones de aprendizaje, establecer una comunicación adecuada con los estudiantes y colegas, trabajar en equipo, entre otras.

Las facultades de medicina deben garantizar las competencias de sus docentes, no solo en las aulas del claustro universitario sino en los escenarios de práctica. La sola vinculación de un médico a un hospital con el cual se tiene convenio de docencia servicio no puede ser suficiente para convertirlo en docente. Es por esto y ante las nuevas circunstancias que se hace necesario mejorar la habilidad de enseñanza de los docentes, deben mejorar sus propias habilidades, con claros conceptos de ampliación de su comprensión pedagógica y superar la resistencia a los cambios que han implicado los nuevos paradigmas en la educación médica, además de las condiciones de contratación.

Deben comprometerse con asegurar mejores prácticas para mejores cuidados especialmente en los centros de enseñanza. El concepto de liderazgo no puede perderse, especialmente cuando se abriga el título de maestro en la educación, exige esta postura una reflexión crítica, personal e institucional que apoye el desarrollo de su ser como docente, que junto con la institución garantice un patrimonio de educación permanente.

La institución debe facilitar independientemente de la situación contractual de sus pagadores un verdadero entorno del aprendizaje, basado en el trabajo, es ahí donde la educación médica ha tenido su verdadero desarrollo, la articulación de redes y sistemas de organización y cultura siguen siendo fundamentales en el proceso educativo, lo cual implica la tutoría y el apoyo al docente y al estudiante.

Es necesario entonces mantener un estímulo permanente para el quehacer docente.

Finalmente el perfil de formación de los estudiantes de medicina del país amerita una reflexión, no tanto en términos de la calidad como de las necesidades mismas del sistema.

Algunas universidades, dentro de su autonomía y en su derecho, han manifestado explícitamente que desean formar médico para la especialización y otras lo hacen tácitamente. Muchas facultades declaran que el perfil de sus egresados está orientado a la salud familiar, comunitaria, a la atención primaria pero las tendencias a la especialización, el tipo de entrenamiento de los docentes y los escenarios de práctica que utilizan no ayudan a este propósito.

La formación de los estudiantes de medicina en escenarios de alta complejidad, además de agravar la situación de docencia servicio al generar un uso ineficiente de este recurso, no favorece la visión del estudiante como médico general y permite que se replique de manera continua el modelo del especialista.

Por lo demás es necesario establecer el justo medio de lo que se pretende con la formación del médico general. Por supuesto debe ser un profesional capaz de realizar actividades de promoción y prevención; pero la competencia que más caracteriza al médico es la de diagnóstico y tratamiento y con un perfil de transición epidemiológica como 
el que tenemos en Colombia nuestro médico no solo tiene que saber sobre enfermedades infecciosas y carenciales, sino que debe formarse en crónicas y degenerativas y en trauma y violencia. En general esta confluencia de patologías ha permitido que tengamos un médico competente en el escenario nacional y también internacionalmente.

La formación del médico debe obedecer a un compromiso de responsabilidad social. Creemos que podemos disentir del Sistema pero que la educación médica y la prestación de los servicios deben estar en función de las necesidades de la población, sin olvidar los procesos de investigación y análisis que durante su vida profesional, le ensenaran incluso a aprender a desaprender, tal como lo exige una ciencia regida entre otras cosas por principios biológicos sometidos a variabilidad de máximos y mínimos.

No es posible hablar del futuro de la medicina si este no está ligado a la educación de su recurso humano prioritario, el médico, a la investigación y a la adaptación al los diferentes modelos de atención. La educación del médico debe necesariamente ir mas allá del aprendizaje de lo que funciona, de tal forma que las reformas de salud, la expansión del conocimiento científico, deben necesariamente abrir un foro permanente sobre el profesional que necesitamos. Es imposible separar la búsqueda de la mejor educación médica posible con la de la mejor atención a los pacientes. 


\title{
EDITORIAL
}

\section{Medical education in Colombia}

\author{
Ricardo H. Rozo Uribe, MD. ${ }^{1}$, Ricardo H. Escobar gaviria, MD . ${ }^{2}$ \\ ${ }^{1}$ Director Ejecutivo ASCOFAME. ${ }^{2}$ Jefe División Educación e Investigación ASCOFAME
}

\begin{abstract}
Unquestionably, there have been significant quantitative changes in medical education during the last fifteen years. As a result, these relevant fluctuations have forewarned about a likely deterioration of the quality of medical education in our country. As an illustration, the domestic supply of medical programs in recent years has increased by just over one hundred fifty percent from 21 in 1992 to 59 in 2011. The regional supply in some cases has multiplied even more.
\end{abstract}

Nevertheless, it is relevant to state that changes in medical education do not occur spontaneously but in concordance to a policy directed at not only opening markets, but also including all social sectors, in this case, with particular regard of Law 1001993 and Act 30 of 1992. The first law established a Social Security System, with a health component that aims universal coverage in a few years, and the second law regulates (deregulates?) higher education and provides the legal conditions that facilitated the growth of medical schools and all disciplines in general.

However, beyond the significant quantitative changes that have occurred in the supply of medical programs, we must say that the country has been instituting a number of instruments to assure quality (both: general in regard to higher education, and specific to health) that have influenced the training of doctors. Moreover, they attempt to remedy both situations that arose as a result of such laws: the lack of regulation to new programs and the declining relation teaching- service.

The High Quality Accreditation by the National Council for Accreditation (CNA) is undoubtedly a very important instrument for the promotion and recognition of the quality of medical schools. In Colombia, 21 schools have been accredited by one, for two or three times. As a matter of fact, there has been a significant effort that makes visible the quality minded schools. ASCOFAME has actively participated in the accompaniment of this process in medicine faculties as well as the CNA, and its statutes promote a compulsory affiliation or enrollment of these schools to it.
The process however raises some concerns that should be explored:

What about those schools that fail to be accredited? This is otherwise a puzzle. The accreditation decision is public, but when the accreditation is denied the result is unknown. Would it be useful as a mechanism of social control and responsibility that the Ministry of Education informs about the negative aspects that led to an accreditation denial? Does the fact that the accreditation process is voluntary means that negative results cannot be made public? What about those who, without any justification (such as developing international accreditation processes) do not want to be credited? If the accreditation process was made mandatory, the question that arises is: whether the ceiling becomes floor, must you create a new ceiling?

The legitimacy and importance of the enhancing process is clear, but it cannot be allowed that only those institutions that enlarge quality programs will be the only ones linked to a quality process. It is necessary that quality processes have greater coverage and provide mechanisms to encourage the involvement of all programs in the country, as well as social sanctions that make that those who are not involved in quality processes cannot remained in force.

Nevertheless, the quality of medical education does not depend exclusively on the university. Educational projects that are enlarged in the university are developed to a great extent in hospitals which accomplish teaching service agreements. Despite attempts to regulate this relationship, the model does not allow effective interaction between the parties for the benefit of doctor's training so far.

The coexistence of several medical programs (therefore educational projects) on the same stage of practice gives as a result that the service institution is in charge of the educational project. These institutions happen not to have an instruction project developed, and they often do not have a structure that allows them to manage the medical instruction. As a result, the university loses the possibility of monitoring and evaluating teaching processes as well 
as controlling the academic development of training programs.

The effort that is made by the education sector to have accredited and good quality programs is undermined with an educational project that dies in an institution where multiple service training institutions converge. Additionally, these teaching service institutions have little progress in the accreditation process of quality in relation to health care and service.

The issue of teaching service requires strong political will in many industries in order to be properly resolved. The law 1438 of 2011 that amends Act 100 of 1993 shows some ways to solve the problem, which we hope will materialize in adequate regulations.

Two additional issues deserve special attention in the multiplicity of variables that affect the quality of a future doctor's performance: medical education and teaching skills regarding the vocational profile that is sought to achieve in the school syllabus.

Since the 60s, last century, the principals of teaching education claimed that it was not enough to be a good doctor but to be a good teacher of medicine, a situation that is becoming more evident. In the last five years, we have insisted on students' skills but little on teachers' skills.

In addition to the mastery of content that teachers must have, they must be trained to understand the processes of teaching and learning, to use existing methodologies in a proper way, including ICT, to make an ethical approach to learning situations, to set an effective communication with students and colleagues, to work in teams, among others.

Medical schools must ensure the competence of their teachers, not only in the classrooms of the faculty but also in practice settings. The mere linkage of a physician to a hospital with which they have teaching service agreement may not be enough to become teachers. That is why and regarding the new circumstances, it is necessary to improve the teaching ability of teachers, to improve their own abilities, with clear concepts of expanding their pedagogical understanding as well as overcoming resistance to changes that have involved new paradigms in medical education, in addition to the conditions of employment.

They must commit to ensuring better care practices especially in schools. The concept of leadership cannot miss, especially when the medical teacher holds the title of educator. In fact, this position requires a critical, personal and institutional support for the development of the individual as a teacher, who along with the institution ensures the provision of permanent education

The institution must provide regardless of the contractual status of its paying a real learning environment, based on work. This aspect is indeed where medical education has had its true development, the articulation of networks and systems of organization and culture that still remain as the core in the educational process. This digest involves mentoring and support for the teacher and the student.

It is therefore necessary to maintain a permanent stimulus for teaching work.

Finally, the profile of training medical students in the country deserves a reflection not so much in terms of quality but the very needs of the system.

Some universities, in their autonomy and their right, have explicitly stated that they want to train doctors to specialize and others do so implicitly. Many schools report that the profile of its graduates is family health, community health, primary care oriented however trends toward medical specialization, the type of teachers' training and practice scenarios do not achieve this purpose. The training of medical students in highly complex scenarios, in addition to worsening the situation of teaching service, it generates an inefficient use of this resource, besides, it is not conducive to the student's vision as a general practitioner and it gives as a result a continuous copycat effect of the model of the specialist.

therwise, it is necessary to establish the right balance of what is intended by the general medical training. Of course, the future doctor must be a professional capable of implementing activities related to promotion and prevention. Nonetheless, the competences characterize doctors are: diagnosis and treatment with a component of knowledge about epidemiological transition as we have in Colombia. Our doctor not only has to know about infectious diseases and deficiencies, but must be trained in chronic and degenerative diseases as well as trauma and violence. In genera terms, this confluence of conditions has allowed us to have a competent physician in the national and international scene.

The doctor's training must be committed to social responsibility. We believe we can disagree with the system but medical education and the provision of services should be geared to the needs of the population, without excluding 
the research and analysis processes during professional life. Moreover, medical instruction must teach even learn to unlearn, as it is required by a science governed by biological principles under high and low variability.

It is not possible to talk about the future of medicine without linking it to education of its individuals as a priority, the medical, research and adaptation to the diverse and different models of care. Medical education must necessarily go beyond learning. Thus, health reforms, the expansion of scientific knowledge, must necessarily open a permanent discussion about professional needs. It is impossible to separate the search for the best medical possible education from the best care and attention to patients. 


\title{
EDITORIAL
}

\section{UMa Visão da educaÇão médica na Colômbia}

\author{
Ricardo H. Rozo Uribe, MD . ${ }^{1}$, Ricardo H. Escobar Gaviria, MD. ${ }^{2}$ \\ ${ }^{1}$ Director Ejecutivo ASCOFAME. ${ }^{2}$ Jefe División Educación e Investigación ASCOFAME
}

\begin{abstract}
Sem dúvida ao longo das últimas três décadas tem se apresentado mudanças significativas quantitativas na educação médica no país que alertaram sobre uma provável deterioração da qualidade da mesma. A oferta nacional de programas médicos aumenta nos últimos anos em pouco mais de 150 por cento de 21 em 1992 para 59 em 2011. A oferta regional, em alguns casos chegou a se multiplicar mais.
\end{abstract}

Porém é apropriado, dizer que essas mudanças não ocorrem de forma espontânea e em conformidade com uma política destinada a abertura, não só dos mercados, mas de todos os setores sociais, e que neste caso incluió a Lei 100 de 1993 e Lei 30 de 1992. A primeira estabeleceu um Sistema Geral de Segurança Social, com um componente de saúde que visa a cobertura universal em poucos anos, e a segunda regulamentou o ensino superior e forneceu as condições legais que facilitaram o surgimento de escolas de medicina e, em geral, de todas as disciplinas.

No entanto, além das alterações significativas quantitativa que ocorreram no fornecimento de programas médicos, devemos dizer que o país tem instituindo uma série de instrumentos de garantia de qualidade (tanto em geral eo ensino superior, como de saúde específicos) que têm influenciado na formação do médico tentando remediar duas situações que ocorreram como resultado de tais leis: a falta de regulamentação dos novos programas ea deterioração das relações ensino-serviço.

Credenciamento de alta qualidade pelo Conselho Nacional de Acreditação (CNA) é, sem dúvida, um importante instrumento para a promoção e reconhecimento da qualidade das escolas médicas; 21 faculdades no país tem sido aprovados por uma, duas é até três vezes. Esta tem sido sem dúvida, um esforço significativo o que torna visível as escolas com qualidade do serviço. ASCOFAME tem participado ativamente no acompanhamento deste processo tanto ás faculdades é com o CNA, e promove nos seus regulamentos a exigência de que suas escolas membros estão ligados a ele.
Du processo, porém surgem algumas preocupações que é desejável explorar: ¿Que acontece com as escolas que deixarem de ser acreditados? Isto é um enigma. A decisão de acreditação é público, porém quando a acreditação é negado o resultado não se fez conhecer. ¿Seria útil como um mecanismo de controle social e responsabilidade que o Ministério da Educação fizera conhecer os resultados negativos? ¿Será que o fato de que o processo de acreditação é voluntária significa que os resultados negativos não podem ser tornados públicos? ¿Que acontece com as que, sem alguma justificação (por exemplo estar fazendo dos processos de acreditação internacional), não queram ser creditadas? Se o processo de acreditação ser obrigatória, surge a questão que é se o telhado se torna chão, haverá que criar outro telhado?

A legitimidade ea importância do processo é claro, mas não podese permitir que ao mesmo só estejam ligadas os programas que per se desenvolver processos de qualidade. É necessário que o processo tenha uma cobertura mais ampla e sejam instalados mecanismos para estimular o envolvimento de todos os programas país, e as sanções sociais que fazam que aqueles que não se vinculem não possan ficar vigentes.

Mas a qualidade da educação médica não depende exclusivamente da universidade. O projetos educacionais que estão se desenvolvendo na universidade se refletem em boa parte nos hospitais com os quais se desenvolvem as relações ensino-serviço e, apesar das tentativas de regular essa relação, até agora o modelo não permite uma interacção eficaz entre as partes, em benefício da formação do médico.

A coexistência de vários programas médicos (por enquanto os projetos educacionais) no mesmo palco de prática faz com que o projeto educacional fique nas mãos da instituição de serviços, que não tem um projeto desenvolvido, muitas vezes não têm uma estrutura que permita gerenciar o ensino e a universidade perde a possibilidade de fazer monitoramento e avaliação de processos de formação e controle do desenvolvimento acadêmico do programa. 
O esforço que se faz a partir do sector da educação para ter programas credenciados e de boa qualidade, termina com um projeto educacional para morrer em uma instituição de serviço confluência de muitas instituições de formação, e se têm poucos avanços no processo de acreditação da qualidade das instituições que prestam serviços de saúde.

A questão do ensino-serviço exige grande vontade política de múltiplos setores, para que possa ser resolvido adequadamente. Lei 1.438 de 2011, que reforma a Lei 100 de 1993 mostra algumas formas para dar saída ao problema que esperamos se concretize nos regulamentos.

Duas questões merecem atenção especial na multiplicidade de variáveis que afetam a qualidade do médico: treinamento e as competências de professores e perfil profissional que está sendo procurado.

$\mathrm{Na}$ formação de professores desde os anos 60 do século passado disse que não era o suficiente ser um bom médico para ser um bom professor de medicina, uma situação que está se tornando mais evidente. Nos últimos cinco anos têm vindo a insistir na formação de competências para os alunos, mas pouco nas habilidades de quem deveria ser 0 professor.

Além de domínio do conteúdo que deve ser dado pelo professor deve ter uma preparação que permite a compreensão dos processos de ensino e aprendizagem, usar corretamente as metodologias existentes, incluindo as TIC, para fazer uma abordagem ética para situações de aprendizagem, estabelecer uma boa comunicação com alunos e colegas, trabalhando em equipe, entre outros.

As faculdades de medicina deve assegurar a competência de seus professores, não só nas salas de aula da faculdade mas em cenários de prática. O envolvimento apenas de um médico para um hospital com o qual se têm contrato de ensino-serviço pode não ser suficiente para se tornarem professores. É por isso que perante as novas circunstâncias se faz necessário melhorar a habilidade de ensino dos professores que devem melhorar suas próprias habilidades, com conceitos claros de ampliar sua compreensão pedagógica e superar a resistência a mudanças que envolveram novos paradigmas em educação médica, bem como as condições de emprego.

Eles devem se comprometer a garantir as melhores práticas para um melhor atendimento, especialmente nas escolas. O conceito de liderança não é para ser desperdiçada, especialmente quando se abriga o mestrado em educação, essa posição exige reflexão crítica, apoio pessoal e institu- cional para o desenvolvimento do seu ser um professor, juntamente com a instituição que garante uma riqueza de educação continuada.

A instituição deve fornecer, independentemente da situação contratual de seus contribuintes um ambiente de aprendizagem real, com base no trabalho, que é onde a educação médica teve o seu desenvolvimento real, a articulação de redes e sistemas de organização e cultura permanece central no processo educacional, que envolve a orientação e apoio aos professores e estudantes.

Portanto, é necessário manter um estímulo permanente para o trabalho docente.

Finalmente o perfil da formação de estudantes de medicina no país merece uma reflexão, não tanto em termos de qualidade como das necessidades mesmas do sistema.

Algumas universidades, em sua autonomia e no seu direito, tem declarado explicitamente que elas desejam formar médico para a especialização e os outros fazê-lo implicitamente. Relatório de muitas escolas dizem que o perfil dos seus diplomados são orientados para a saúde da família, da comunidade, cuidados primários, mas a tendência para a especialização, o tipo de formação de professores e os cenários de prática utilizada para esta finalidade não ajuda.

A formação de estudantes de medicina em cenários altamente complexos, além de agravar a situação de ensino-serviço ao gerar um uso ineficiente desse recurso, não contribuem para a visão do aluno como um clínico geral e permite que ele replicar o modelo continuamente especialista.

Alêm disso, é necessário estabelecer o equilíbrio certo do que se pretende com a formação médica geral. Claro que deve ser um profissional capaz de atividades de promoção e prevenção; mas a competência que mais caracteriza o médico é o diagnóstico e tratamento e com uma transição epidemiológica como temos na Colômbia o nosso médico não só precisa saber sobre doenças infecciosas e deficiências, mas devem ser treinados em crônicas e degenerativas e trauma e violência. Em geral, essa confluência de condições nos permitiu ter um médico competente no cenário nacional e internacional.

A formação do médico deve seguir um compromisso com a responsabilidade social. Acreditamos que podemos discordar de sistema, mas que a educação médica e à prestação do serviços devem ser orientados para as necessidades da população, sem esquecer os processos de pesquisa e aná- 
lise que durante sua carreira, ensinou-lhe ainda aprender a desaprender, como exigido por uma ciência regida entre outras coisas, pela variabilidade dentro dos princípios biológicos de máximos e mínimos.

Não é possivel falar sobre o futuro da medicina, se não está ligado à educação de seu recurso humano essencial, o médico, á pesquisa, e adaptação dos diferentes modelos de cuidado. $\mathrm{O}$ educação médica deve necessariamente ir além do aprender o que funciona, de modo que as reformas de saúde, a expansão do conhecimento científico, deve necessariamente abrir um fórum permanente sobre a necessidade profissional. É impossível separar a busca da melhor educação médica possível com o melhor atendimento aos pacientes. 